\section{$2 \mathrm{I1315}$}

ダイニンストークとキネシンの微小管結合における 競合

○水野直子、西井淳子、枝松 正樹、豊島陽子（東大院·棇 合文化·生命

ダイニンとキネシンは微小管上を逆向きに運動する分子モーターで

ある。これらがチューブリンの同一サイトを認識しているかを明らか にするために、競合実験を試みた。

ダイニンにおいては、微小管と直接結合するのはストーク領域で あることが知られており、リコンビナントのストークを用いることに より、巨大なダイニン分子の立体的な阻害を起こすことなくキネシン と相互作用寸ることが可能となる。ストークの棒状部分の 2 次構造 に着目し、微小管結合能のあるフラグメントを大腸菌で発現した。そ の結果、可溶性で単量体である $17 \mathrm{k}$ フラグメントを得た。この $17 \mathrm{k}$ ス トークは、微小管にチューブリンダイマーの約 2 倍量結合したので、 チューブリンに対して1：1で結合するキネシンとは異なり、複数の 認識部位を持つ可能性がある。

ガラス面上にウシ脳から得られたキネシンを吸着させ、微小管と 17k ストークの混合物を加え in vitro motility assayによりキネシン の運動を観察した。微小管の3倍量のストークを混合した状態では 17k ストークを混合していない微小管と比較し、すべり運動速度は70 \%、10倍量では 30 \%と大きく隇少した。これは、キネシンのクロス ブリッジサイクルのうち、17k ストークにより阻害されている過程が あることを示唆している。また、微小管一 $17 \mathrm{k}$ ストーク複合体と単頭 キネシンを共沈させると、加える単頭キネシンの量が増えるにつれ共 沈する $17 \mathrm{k}$ ストークの量が隇る、という競合現象が見られた。以上よ り、ダイニンは微小管上に複数の認識部位があり、その一部がキネシ ンと認識部位を共有している可能性が高いことが示された。

N.Mizumo, J.Watai-Nishii, M.Edamatsu and Y.Y.Toyoshima : Competiton between dynein stalk and kinesin in binding to microtubules

\section{$2 \mathrm{I} 1345$}

尿素処理によるテトラヒメナ外腕ダイニンの活性を 持つ重鎖の解離

O鳥羽秝 ${ }^{1}$ 、城口克之 1 、Gibson. Tracie ${ }^{2} 、$ Asai. David J. ${ }^{2}$ 、豊 島 陽子 ${ }^{1}$ ( ${ }^{1}$ 東大院·総合文化·生命環境科学、 ${ }^{2}$ Dept. of Biol. Sci.. Purdue Univ.)

我々は、尿素によって Tetrahymenaの外腕ダイニンを単頍部と双 頭部に分離し、活性のあるフラクションを得る事が出来た。

Tetrahymenaの䄉毛の外腕を構成する $22 \mathrm{~S}$ ダイニンは、3つの異な る重鎖を持つへテロ 3 量体である。それぞれ、 $\alpha 、 \beta 、 \gamma$ と呼ばれる この3つの重鎖から出来たへッド部分は、ステム部分で東枋られて、 花束(プーケ) 状の構造を形作っている。それぞれの重鎖は、異なる 機能を持つと想像されるが、まだ明らかでない部分が多い。また、こ のダイニンは分子量約 200 万にも及び、構造が複雓で、遺伝子工学的 に各重鎖を得る事は困難である。

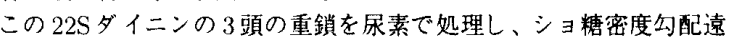
心にかけると、双頭部 $(\beta 、 \gamma)$ と単頚部 $(\alpha)$ に分離された。この尿 素での処理は、タンパク質分解醭素による分離と異なり、重鎖の全辰 を保持した状態で分離する事が出来た。

こうして得られたフラグメントは、ATPase 活性、微小管結合能や 滑り運動活性があった。また、尿素を取り除く過程で再び3頭のダイ ニンに戻る現象が観察され、この処理が可逆的である事がわかった。

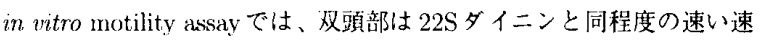
度で微小管を滑らせる事が出来た。单頭部は、現在までの実験では、 微小管を結合できるものの、ATPに依存した結合能は示さず、滑り 運動も起こしていない。

尿素の処理により活性を持つダイニンフラグメントが得られた事 は、ダイニンの分子構造の特性に示唆を与えるとともに、他の様々な 種類のダイニンに応用する事により、それらの機能の解明に役立つも のと期待されている。

S.Toba.K.Shiroguchi.T.Gibson.D.J.Asai and Y.Y.Toyoshima : Dissociation of functional dynein heavy chains of Tetrahymena outer arm by urea treatment

\section{$2 \mathrm{I} 1330$}

\section{細胞質ダイニン 1 分子の運動連続性}

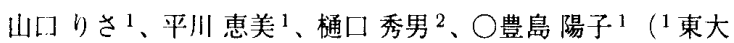
院·棇合文化·生命、 2 東北大 $\cdot$ 工・金属 $)$

ウシ脳から精製した細胞質ダイニン（MAP1C）を結合したマイク ロビーズの微小管上での運動を、光ピンセットを組み込んだ光学系で 計測した。ダインンビーズの混合比を変え、AMP-PNP 存在下で 微小管に結合するビーズの割合と ATP 存在下で微小管上を運動する ビーズの割合を調べな結果、ダイニン 1 分子が微小管上を連続的に運 動できることがわかった。運動の方向はキネシンとは反対で微小管の マイナス端に向かい、1 分子の最大力は的 $4.3 \mathrm{pN}$ 、力-速度関係は直線 的であった。さらにダイニン分子の一歩の大きさと思われる基本的な 変位のサイズとして $8 \mathrm{~nm}$ が検出された。

興味深いことに、細胞質ダイニン1分子の運動は、ATPの濃度が 高い方が連続的で長い距離を運動することができた。この光ピンセッ トの捕捉の中を進むビーズの移動距離の ATP 濃度依存性を、細胞質 ダイニン、軸系外腕ダイニン、キネシンについて調ベ、8n m ステッ プを刻むごとに微小管から外机る確率を比較した。その結果、キネシ ンは微小管から外れる確率は ATP 濃度によらずほほ一定で低く、細 胞質ダイニンはATP 濃度が高いほど外れる確率が低くなり、軸系ダ イニンは反対にATP 濃度が高くなるほど外れる確率が高くなる、と いう特徽が明らかになった。これらの結果は、3種のモーターに执 て、結合ヌクレオチドの状態により微小管との親和性が巽なることを 示唆している。

L.Yamaguchi, E.Hirakawa, H.Higuchi and Y.Y.Toyoshima : Motility of single molecule of cytoplasmic dynein

\section{I1400}

\section{ダイニンモータードメインに存在する 4 つの P-loop の機能解析}

○西浦昌哉、大倉玲子、昆 隆英、須藤和夫（東大·院総合 文化)

タイニンは重鎖、中間鎖、軽中間鎖および軽鎖の 4 種類のサブユニッ トにより構成されるモータータンパクである。重鎖は巨大な球状のド メインを持ち、ATPの加水分解及び微小管との相互作用を司ってい る。アミノ酸の一次構造配列から、重鎖にはP-loop と呼ばれるヌク レオチド結合を示晙する配列が 4 カ所あり、4つのループすべてがヌ クレオチドを結合すること、また $\mathrm{N}$ 末端に最も近い P-loopが ATP加 水分解活性を持っていることなどが推測されている。しかし、なぜ4 力所もヌクレオチド結合部位があるのか、あるいは ATP 加水分解や 微小管との相互作用に打いて、それぞれのループがどんな役割を果た しているのかについては、よくわかっていない。

そこで本研究では、4つのP-loopに着目し、それぞれのループのヌク レオチド結合能をなくした細胞性粘菌ダイニン重鎖 mutant 、GFP との融合タンパクとして粘菌細胞で発現させ、それぞれの P-joopの 機能を、細胞生物学的手法を用いて解析した。

GFP融合ダイニン重鎖を発現させた細胞を観察したところ、N末端 から 3 番目の P-loopの mutant が、細胞内で微小管と固く結合して いる様子が見られ、このループが微小管との相互作用もしくは ATP 加水分解活性に対して何らかの調整機能を持っていることが示唆され た。一方、 4 番目のループの mutantは、細胞内で wild type と差の ない挙動を示した。

また、ADP-バナジン酸を結合させ、紫外線照射によってタンパク質 を切断する実験を行った結果、この二つの mutantは共に1番目のP. loopで切断された。よってそれぞれの mutantでは、1 番目のP-loop の ATP 結合能は維持されていることが示唆された。

今後は、残りの P-loopの mutantにおいても同様の実験を行い、各 P-loopの役割を明らかにしていく予定である。

M.Nishiura, R.Ohkura, T.Kon. K.Sutoh : Functional analysis of four P-loops of the dynein motor domain 